\title{
Proses Pengambilan Keputusan
}

\author{
Ahmad Rifa'i \\ Universitas Negeri Padang \\ Indonesia \\ E-mail : ahmadrivay466@gmail.com
}

\author{
Hade Afriansyah \\ Universitas Negeri Padang \\ Indonesia \\ E-mail : hadeafriansyah@ fip.unp.ac.id
}

\author{
Rusdinal \\ Universitas Negeri Padang \\ Indonesia \\ E-mail : rusdinal@fip.unp.ac.id
}

\begin{abstract}
Abstrak-The main meaning of decision-making is an act issuing a decision that is both tactical and operational such as planning programs to be achieved, implementation strategies and problem solving strategies, through a decision based on the election results of several solution alternatives decided to achieve goals.
\end{abstract}

Keyword: Decision Making

\section{Pendahuluan}

Membuat keputusan merupakan bagian dari kehidupan kita sehari-hari baik secara individu ataupun secara kelompok, terutama dalam suatu organisasi.Pengambilan keputusan mempunyai arti penting bagi maju atau mundurnya suatu organisasi. Pengambilan keputusan yang tepat akan menghasilkan suatu perubahan terhadap organisasi ke arah yang lebih baik, namun sebaliknya pengambilan keputusan yang salah akan berdampak buruk pada roda organisasi dan administrasinya.

Keputusan dan kebijakan merupakan alat untuk mencapai tujuan yaitu menjadikan madrasah sebagai lembaga yang memiliki standar pendidikan.Pembuatan keputusan juga dilihat sebagai suatu proses dominan seseorang (pembuat keputusan) memilih dari dua atau lebih alternatif tindakan yang memungkinkan. Proses dominan kepala madrasah memilih dua atau lebih alternatif tindakan yang memungkinkan mulai dari dasar, gaya, teknik dan teknik pelibatan stakeholder.

\section{Metode}

Metode yang digunakan dalam artikel ini adalah metode Systematic Literature Review (SLR), yaitu dengan terlebih dahulu mengumpulkan bahan-bahan kajian terkait administrasi/manajemen pendidikan baik berupa buku, artikel, dan sumber lainnya. Setelah bahan kajian dikumpulkan, selanjutnya bahan tersebut diteliti dan dipelajari, kemudian penulis berusaha menyimpulkan sebuah pengetahuan baru hasil dari analisis terhadap bahan kajian tersebut.

\section{KaJian Teori dan Pembahasan}

Bagian ini merupakan bagian inti dari penulisan artikel. Karena bagian ini memuat bahan kajian dan pembahasan teori yang diteliti mengenai pengambilan keputusan. Setiap individu atau kelompok pasti pernah dihadapkan kepada beberapa pilihan. Keputusan (decision) berarti pilihan (choice) yaitu pilihan dari dua atau lebih kemungkinan. Setiap keputusan yang diambil memiliki kadar kemungkinan yang berbeda-beda, oleh karena itu sebagai seorang pemimpin harus benar-benar paham terhadap suatu keputusan yang diambilnya.

\section{Pengertian Pengambilan Keputusan}

a. Pengertian keputusan menurut Morgan dan Cerullo (1984) dalam (Salusu, 2015)

Morgan dan Cerullo mengemukakan bahwa keputusan adalah sebuah kesimpulan yang dicapai setelah melakukan beberapa pertimbangan, yang telah tetjadi setelah satu kemungkinan dipilih sementara yang lain dikesampingkan.

b. Pengambilan Keputusan Menurut GR Terry (2016:138)

GR Terry (2016:138) menyatakan dalam Connie Chairunnisa "Decision making can be defined as the selection based on same criteria of one behaviore alternative from two or more possible alternative”. yang artinya pengambilan keputusan merupakan proses seleksi yang berdasarkan dari beberapa kriteria yang berupa suatu tindakan terdiri dari dua atau lebih kemungkinan alternative. 
c. Pengambilan Keputusan Menurut Morhead dan Griffin(2014:174)

Morhead dan Griffin (2014:174) menyatakan (dalam buku Meningkatkan Kinerja Kepala Sekolah/Madrasah Melalui Managerial Skills oleh Helmawati) menyatakan bahwa aturan untuk mengambil keputusan menuntut para pemimpin untuk mencari informasi untuk digunakan dalam pengambilan keputusan dan kemudian mengkomunikasikan keputusan-keputusan tersebur kepada yang lain.

\section{d. Pengambilan Keputusan Menurut Salusu (2011:164)} Salusu (2011:164)

Menyatakan (dalam buku Anatomi Oranisasi dan Kepemimpinan Pendidikan oleh Abdul Aziz Wahab). Keputusan merupakan sebuah kesimpulan yang dicapai sesudah dilakukan pertimbangan, yang terjadi setelah satu kemungkinan dipilih, sementara yang lain dikesampingkan. Yang dimaksud dengan pertimbangan ialah menganalisis beberapa kemunkinan atau alternatif, lalu memilih salah satu diantaranya.

e. Pengambilan Keputusan Menurut Sondang P.Siagian (2016:138)

Sondang P.Siagian (2016:138) menyatakan(dalam buku Manajemen Pendidikan Dalam Multi Perspektif oleh Connie Chairunnisa) menyatakan, "Pengambilan keputusan adalah sesuatu pendekatan yang sistematis terhadap hakikat suatu masalah pengumpulan fakta-fakta dan data, penentuan yang matang atas alternatif yang dihadapi dan mengambil tindakan yang paling tepat

\section{f. Pengambilan Keputusan Menurut Steers}

Steers mengemukakan bahwa "decision making is a process of selecting among available alternatives". Di sini jelas bahwa pengambilan keputusan menyangkut pilihan dari berbagai macam alternatif yang ada dalam organisasi. Selanjutnya Koontz mengatakan bahwa pengambilan keputusan merupakan seleksi berbagai alternatif tindakan yang akan ditempuh merupakan inti perencanaan (Koontz, 1998)

g. Menurut Harren (1980)

Tiap-tiap orang belajar mengandalkan suatu cara terbaik yang berlaku atas dirinya sesuai dengan pengalammnya.

h. Menurut Suharnan (2005)

Pengambilan keputusan adalah proses memilih atau menentukan berbagai kemungkinan diantara situasi-situasi yang tidak pasti.

i. Sweeney dan Farlin Dalam Sarwonno (2009)

Mendefinisikan pengambilan keputusan sebagai proses dalam mengevaluasi satu atau lebih pilihan dengan tujuan untuk meraih hasil terbaik yang diharapkan

j. Kinicki dan Kreitner dalam Sarwono (2009)

Mendefinisikan pengambilan keputusan sebagai proses mengidentifikasi dan memilih solusi yang mengarah pada hasil yang diinginkan

k. Menurut Davis dalam Hasan (2002)

Pengambilan keputusan adalah pemilihan alternatif perilaku (kelakuan) tertentu dari dua atau lebih alternatif yang ada.

\section{Dalam (Zaleny 1973).}

Decison making is a dynamic process: a complex search for information, full of detours, enrich by feedback from casting about all directions gathering and discarding information

\section{Proses Pengambilan Keputusan}

Proses pengambilan keputusan adalah suatu usaha yang rasional dari administrator untuk mencapai tujuan-tujuan yang telah ditetapkan pada bagian awal dari fungsi perencanaan. Prosesnya mulai dan berakhir dengan pertimbangan. Ia memerlukan kreativitas, keterampilan kuantitatif dan pengalaman.

Urutan-urutan langkah-langkahnya dalam oteng dalam Nurs (2003) yaitu sebagai berikut:

1) Penentuan masalah,

2) Analisa situasi yang ada,

3) Pengembangan alternatif-alternatif,

4) Analisa alternatif-alternatif,

5) Pilihan alternatif yang paling baik.

Dalam mengambil sebuah keputusan, harus memperhatikan hal-hal sebagai berikut dalam Nurs (2003):

a) Dalam proses pengambilan keputusan tidak terjadi secara kebetulan.

b) Pengambilan keputusan dilakukan secara sistematik, yaitu: tersedianya sumber- sumber untuk melaksanakan keputusan yang akan diambil, kualifikasi tenaga kerja yang tersedia, falsafah yang dianut organisasi, situasi lingkungan internal dan eksternal yang akan mempengaruhi administrasi dan manajemen di dalam organisasi.

c) Masalah harus diketahui dengan jelas.

d) Pemecahan masalah harus didasarkan pada faktafakta yang terkumpul dengan sistematis.

e) Keputusan yang baik adalah keputusan yang telah dipilih dari berbagai alter- natif yang telah dianalisa secara matang.

Dalam Nurs (2003) Apabila pengambilan keputusan tidak didasarkan pada kelima hal di atas, akan menimbulkan berbagai masalah:

a) Tidak tepatnya keputusan.

b) Tidak terlaksananya keputusan karena tidak sesuai dengan kemampuan organisasi baik dari segi manusia, uang mau-pun material.

c) Ketidakmampuan pelaksana untuk bekerja karena tidak ada sinkronisasi antara kepentingan organisasi dengan orang- orang di dalam organisasi tersebut.

d) Timbulnya penolakan terha- dap keputusan.

Thohiron dalam Wahab (2011) menjelaskan proses pengambilan keputusan meliputi sebagai berikut:

1. Perumusan Masalah

Dalam hal ini pemimpin diharapkan mampu merumuskan masalah yang ada di dalam suatu organisasi. Suatu masalah hadir karena: 
a) Adanya gap atau kesenjangan antara kenyataan, titik berangkat, dengan tujuan yang ingin diraih atau standar yang ingin dicapai.

b) Adanya halangan dan kesulitan untuk menjembatani kesenjangan itu.

c) Adanya kemungkinan penyelesaian masalah bila perumusannya benar.

2. Pengumpulan dan Penganalisis Data

Pemimpin diharapkan dapat mengumpulkan dan mengana-lisis data yang dapat membantu memecahkan masalah yang ada. Adapun proses pemecahan masalah dalam pengambilan keputusan yaitu:

a) Fase pengumpulan fakta.

b) Fase penemuan ide.

c) Fase penemuan solusi.

3. Pembuatan alternatif-alternatif kebijakan

Untuk mengadakan perkiraan dibutuhkan adanya informasi yang secukupnya dan metode perkiraan yang baik. Perkiraan itu terdiri dari berbagai macam pengertian:

a) Perkiraan dalam arti proyeksi, perkiraan yang mengarah pada kecenderungan dari data yang telah terkumpul dan tersusun secara kronologis.

b) Perkiraan dalam arti prediksi, perkiraan yang dilakukan dengan menggunakan analisis sebab akibat.

c) Perkiraan dalam arti konjeksi, perkiraan yang didasarkan pada kekuatan intuisi (perasaan). Intuisi di sini sifatnya subjektif, artinya tergantung dari kemampuan seseorang untuk mengolah perasaan.

4. Pemilihan salah satu alternatif terbaik

Pengambilan keputusan oleh pimpinan, kaitannya dengan pemilihan alternatif pemecahan masalah, akan melibatkan semua pihak yang terlibat dalam lembaga pendidikan. Hal ini karena kekuasaan pimpinan tidak dapat dioperasionalkan apa- bila tidak didukung dan dibantu oleh seluruh personal yang memiliki pengetahuan dan pengalaman yang berbeda-beda.

Dalam Hikmat (2009) Pimpinan harus mengembangkan konsep kerja sama antar personal agar pelaksanaan alternatif pemecahan masalah lebih cepat dan mudah. Kerja sama dapat diciptakan jika pimpinan memiliki keterampilan manusiawi.

5. Pelaksanaan keputusan

Dalam pelaksanaan keputusan berarti seorang pemimpin harus mampu menerima dampak yang positif atau negatif. Ketika menerima dampak yang negatif, pemimpin harus juga mempunyai alternatif yang lain. Pelaksanaan pengambilan keputusan sering menjadi masalah karena keputusan yang mesti ditanggapi oleh banyak orang malah ditangani oleh sedikit orang.

6. Pemantauan dan Pengevaluasian Hasil Pelaksanaan Setelah keputusan dijalankan seharusnya pimpinan dapat mengukur dampak dari keputusan yang telah dibuat. Penilaian ulang perlu diadakan. Faktor-faktor penentu yang akan dinilai harus diputuskan sejak awal dan tidak setelah pelaksanaan ber-jalan. Dengan cara ini memang akan mudah terjadi debat yang hangat, namun akurasi akan lebih terjamin.

Berdasarkan pendapat pada ahli di atas, maka disimpulkan tahapan proses pengambilan keputusan yang dimaksud dalam penelitian ini adalah:

1) Perumusan masalah,

2) Penentuan kriteria pemecahan masalah,

3) Pengidentifikasian alternatif pemecahan masalah,

4) Penilaian terhadap alternatif peme- cahan masalah,

5) Pemilihan alternatif yang terbaik, penetapan keputusan atau pengimplementasian alternatif yang dipilih.

\section{Teori Pengambilan Keputusan}

a. Model Tempat Sampah (the garbage can model)

Model tempat sampah dimana sampah dapat melihat atau menggambarkan pengambilan keputusan dalam "anarki terorganisir" didasarkan pada karya (Cohen MD, 1972). Model kaleng sampah menekankan fragmentasi dan sifat kacau pengambila keputusan dalam organisasi, dari pada manipulasi yag disegaja yang disirakan oleh pandangan politik.

b. Model Perspektif Perbedaan Individu (the individual differences perspective)

Model perspektif perbbedaan individu ini mencoba menjelaskan bagaimana manajer dapat mengunakan metode yang berbeda atau sampai pada kesimpulan yang berbeda karena kepribadin yang berbeda, misalkan selain dari (Keen PGW \& Scott Morton MS, 1978)perspektif perbedaan individu belum mendapat banyak perhatian karena penekanan keseluuhan di tempat lain pada organsasi (atau kelompok) dari pada pengambilan keputusan indiviu.

c.Pengambilan Keputusan Alami (naturalistic decissin making)

(Turpin \& Marais, 2004) pengambilan keputusan naturalistik berkaitan dengan penyelidikan (investigasi) dan pemahaman pengambilan keputusan dalam konteks yang natural. Landasan empiris dari pengambilan keputusan naturalistik menbedakannya dari model deskriptif lainnya, seperti prosedur 
organisasi, tempat sampah tau pandangan politik. Baru-baru ini kontroversi bidang pengambilan keputusannaturalistik adalah bahwa model Klein's Recognition-Primed Decision (RPD). Dimana Klein mengamati dan/atau menganlisis lebih dari 600 keputusan yang dibuat oleh orang-orang dalasituasi berbeda, seperti petugas, perawat, dan tentara.

d. Pendekatan Multi Perspektif (the multiple perspective approach)

\section{KeSIMPULAN}

Berdasarkan uraian di atas, maka dapat disimpulkan bahwa proses pengambilan keputusan terdiri dari (1) perumusan masalah (2) pengumpulan data (3) pembuatan alternative (4) pemilihan alaternatif (5) pelaksanaan keputusan (6) pengevaluasian.

\section{Daftar Pustaka}

Cohen MD, M. J. \& O. J. (1972). A Garbage Can Model Of Oganizational Reprinted in March JG, 1988, Decisions and Organizations, Basil Blackwell, Oxford.

Hasan. 2002. Pokok-Pokok Metodologi Penelitian Dan Aplikasinya. Jakarta: Ghalia Indonesia.

Harren, V. A. 1980. Assesment of Carner Decision Making. Los Angelos: Western Psychologicl Services.

Hikmat.2009. Manajemen Pendidikan,Bandung: Pustaka Setia

Keen PGW \& Scott Morton MS. (1978). Decision Support Systems: An organizational perspektif, Addison,-wesley, Reading (MA).

Koontz. (1998). Manajemen, terj. Jakarta: Erlangga.

Mtroff II \& Linstone HA. (1993). The unbounded mind, Oxford University Press, New York (NY).

Nurs. 2003. Pengambilan Keputusan. Jakarta: Gunung
(Mtroff II \& Linstone HA, 1993) mengusulkan pendekatan multi perspektif untuk pengambilan keputusan sebagai upaya untuk "menyapu" semua kemungkinan perspektif pada suatu masalah. Ini didasarkan pada konsep Singer dan Churchman (1971) tentang pemikiran sistem tanpa batas, yang asumikan bahwa masalah apa pun adalah anggota dari masalah lain apapun.

Agung.

Turpin, S. M., \& Marais, M. A. (2004). Decision-making: Theory and practice. ORiON, 20(2), 143. https://doi.org/10.5784/20-2-12sion-making: Theory and practice. ORiON. https://doi.org/10.5784/20-2-12

Cairunnisa, Connie.2016.Manajemen Pendidikan Dalam Multi Perspektif.Jakarta: Rajawali Pers.

Gitosudarmo Indriyo.2000. Perilaku Keorganisasian. Yogyakarta: BPFE.

Helmawati. 2014. Meningkatkan Kinerja Kepala Sekolah/Madrasah melalui Managerial Sklills.Jakarta: Rineka Cipta.

J. Supranto.2009.Teknik Pengambilan Keputusan.Jakarta: Rineka Cipta.

Sarwono. 2009. Buku Acuan Nasional Pelayanan Kesehatan Maternal Dan Neonatal. Jakarta: YBP-SP.

Sondang P. Siagian.2005.Fungsi-Fungsi Manajerial. Jakarta: Bumi Aksara.

Wahab, Abdul Aziz. 2011. Anatomi Organisasi dan Kepemimpinan Pendidikan. Bandung:Alfabeta.

Zaleny. 1973. Pengambilan Keputusan Beberapa Kriteria. Columbia: Universitas Carolina Selatan Press. 